\title{
WORK-LIFE BALANCE: A CASE STUDY ANALYSIS ON GOOGLE AND A COMPARATIVE STUDY OF PRACTICES FOLLOWED IN NORWAY AND INDIA
}

\author{
Miss Deepa Singh \\ Assistant Professor, Government Nehru PG college, \\ Burhar, Distt- Shahdol (M.P), India
}

\begin{abstract}
The concept of work life balance emerged during the Industrial Revolution. In those days Industrialists agreed upon labour union's demand of 'One day off'. Later on, this is converted into 'two day off' which is followed in all the western countries. Grady et al (2008) stated that the term' work-life balance' is more comprehensive and includes "family, community, recreation and personal time."
\end{abstract}

The objectives of the research are to study the impact of practices followed in Norway and India on work-life balance, to gain insight on Google company's work-life balance practices, to identify and suggest vital work-life balance practices that can be applied in Indian context. The research is descriptive in nature. The data has been collected mainly from secondary sources - research papers, annual report of companies (employee engagement) and articles.

The tools used for achieving objectives and analysing are comparison method, case study analysis and survey method. The comparative and case study analysis shows that the education system, job security, income inequality are some of the factors which hinder the work-life balance in India. Flexi hours, time for creativity, family participation in workplace boost the enthusiasm and morale of the employees.

The research is based on secondary sources. The primary data would more effectively convey the problems faced in work life balance. The work-life balance practices followed by only one company is taken into the study due to time constraint. The comparative analysis of work-life balance practices of big films would give better insight and would help in deriving dynamic solution. The sector centred, institution centred or gender centred study will give broader overview of the work-life balance. The search acts a base for comparative analysis.

Keywords- Work-life balance, stress, employee, family, company.

\section{INTRODUCTION}

In our daily life balance is the ultimate objective for which we thrive. The concept of work life balance emerged during the Industrial Revolution. In those days Industrialists agreed upon labour union's demand of 'One day off'. Later on, this is converted into 'two day off' which is followed in all the western countries. But looking into the present scenario can any working professionals afford to switch off communication tools and spend time in peace. The answer is 'no'. There is an exigency of work-life balance in order to live our life happily and peacefully.

The philosophy of work life balance pivots around managing work with other activities of life. These activities comprise many aspects like sharing time with family, peers, pursuing hobbies or engaging in any activity which gives comfort. Grady et al (2008) stated that the term' work-life balance' is more comprehensive and includes "family, community, recreation and personal time." Frone (2003) defined worklife balance as "low levels of inter role conflict and high levels of inter role facilitation." The research is conducted with an objective to have overview of various work-life balance practices performed with two broad dimensions. The first dimension is a comparison of Indian practices and Norwegian practices and the second dimension is a case study on worklife balance practices performed in Google.

\section{LITERATURE REVIEW}

Chaitra R, Ashok kumar RS, JP Renuka Murthy in the research paper titled as "A study on work life balance of the employees at Bosch Ltd, Bangalore "examines the factors affecting work-life balance. The findings of the study say that work is having a negative effect on the employees of the company. The overtime workings and anytime meetings are the main factors which deteriorate the balance. But at the same time policy on free flow of communication between supervisors, flexible working hours, engagement of family in office celebration is most appreciated and has a positive impact on the work of the employees.

Clark (2008) in his border theory of work life balance stated that work-life balance is influenced by physical factors (office space), temporal factors (hours spent on working) and psychological borders (thinking pattern) between work and family settings. He proposed two approaches for employee's wellbeing the first is keeping work and life separate and 


\section{International Journal of Engineering Applied Sciences and Technology, 2020 Vol. 5, Issue 8, ISSN No. 2455-2143, Pages 273-277 \\ Published Online December 2020 in IJEAST (http://www.ijeast.com)}

second is integration of work and family. The adaptability of the approach depends on the profile of the employee.

Hema Mirji and Dr. Kirti Gupta in the research work "Indian perspective on work-life balance" cited the privileges owned by Indian families. These are privileges of joint family, number of more earning members, pension of father or mother, close proximity with social groups. All these factors reduce the financial burden up to some extent and increases the emotional support of a person.

\section{OBJECTIVES}

1. To study the impact of practices followed in Norway and India on work-life balance.

2. To gain insight on Google company's work-life balance practices.

3. To identify and suggest vital work-life balance practices that can be applied in Indian context.

\section{Research Methodology}

The research is descriptive in nature. The data has been collected mainly from secondary sources - research papers, annual report of companies (employee engagement) and articles.

The tools used for achieving objectives and analysis are comparison method, case study analysis and survey method.

\section{A Comparative study on practices followed in Norway and India and its impact on work-life balance}

Norway is one of the happiest countries in the world according to World Happiness Report whereas India stood at 144 rank with total of 156 countries. There are some practices and philosophies followed in India that are detrimental to the social and personal development of a person.

- Education- Education is the key component for the development of any country. In India the education system is manifold. There is a thick line between government institutions vs. private institutions. The financial status and social standing of a person is revealed by the schools in which their children study.

Norway has developed an advance public school which is up to some extend free for the children. Moreover, there are no grades or marks given at primary level. The primary focus is learning. It means parents need not to worry about the money for getting admissions in top schools

The Imbalance - In India the major expenditure of any parent is on education. The private schools demand huge fees which occupies more than half of the salary of the parents. This forces to work overtime or find an alternative work. This creates a gap between the personal life and professional life of a person and makes a person more stressful.

- Job security - This is the main aspect for balancing your life. In India firing an employee is a common practice. If you are a late comer, if you do not understand well how you have to do your work, if you have been absent from workplace for many days or if you are not satisfying the esteem of employers then you could expelled from your job.

In Norway firing an employee is the most uncommon practice. An employer cannot fire an employee for underperforming rather he should provide an alternative work of the same level.

The Imbalance- Job security is the ultimate aim of our career in India. To maintain this an employee not only have to complete the overburdened work but also has to maintain an attitude of 'I can do anything anytime' which makes a person suffering from inside who generally resort to means which are unhealthy for themselves and the family.

- Income inequality- In our country we interpret that education imparts skill. Hence the person who is uneducated is considered as unskilled. The financial assistance earned by any person depends upon its hierarchy in the organisation. We never applied the principle of every work is equal in all respect. Moreover, due to gender inequality, women are paid less as compare to fellow male members.

In Norway- Norway ranks top for overall equality. According to Human Development Index, Norway has some of the lowest paid CEO's in the world. It implies they primarily support and follow the concept of work equality among every sector and irrespective of gender.

The Imbalance- India find its position at top in terms of income inequality. The salary and wages lower level employees is many times lower than the high-level employees - the CEO and managers. Income inequality to some extend makes a person vulnerable in front of the society. The farmers and labours of our country are mostly affected due to this inequality. They resort to credit which is either taken from moneylenders at high interest rate or by bank which takes the ownership of the collateral in case of non-payment of interest.

- Volunteering- In our country volunteering is assumed as work of Non-Governmental organisations. We hardly encourage or appreciate our employees to participate in these activities as we believe that working for job is the only means of development of the institution.

In Norway, every organisation involves in some volunteering activity be it planting, cleaning roads, clean up their cubicles in a week, child development programme and the employees who wish to get engaged themselves are given half day off.

Work Life Balance- The act doing for someone without any personal benefit gives an essence of joy within ourselves. These practices create amicable and compassionate environment in our family which ultimately brings happiness.

- Dry Season off - In India an employee is always an employee whether they had work for doing or not. It implies visiting office is the due times is an important culture in India. This segment takes a 


\section{International Journal of Engineering Applied Sciences and Technology, 2020 Vol. 5, Issue 8, ISSN No. 2455-2143, Pages 273-277 \\ Published Online December 2020 in IJEAST (http://www.ijeast.com)}

broader aspect if we take an overview of Government departments.

In Norway there is a concept of Summer time off. A study shows that in the summer time Norwegians commonly take off about four weeks. It is a common practice which is followed by majority of the citizens. Due to this the pace of work in every sector slowdown. This is the time when they most enjoy with the nature without addressing their work.

Work life balance- In India this Covid-19 period is a 'long off' which made us realise the aspirations and advantages of spending time with our family members. There are seasons or times when there is absolutely no work. This is the best time to utilise to have fun with the family or involve ourselves in the work which we really love to do. This gives a feeling of completeness which not only makes us efficient in work but also expand the horizon of life.

\section{Case Study Analysis on Work-Life Balance practices performed by Google}

Google recommends that "treat HR interventions like a medical researcher treats a drug trial: have a treatment group and an equivalent control group, hypotheses, a data collection period, an analysis comparing groups, and quantifiable outcomes."

The founders of the Google Larry page and Sergey Brin focussed on two aspects in early days. The first was creating a better place to find information and second was making the company a best place to work. These are the some of the best scientific practices at Google-

- Google conducts a long-term survey with scientific approach named gDNA. The earlier findings of the survey gave a picture of two kinds of people working in organisation - 'segmentors' and 'integrators.' The Segmentors is the category who do not find any difficulty in switching their profiles. It means the moment they left the workplace they would think of the same when they would arrive the next day. Integrators are opposite to segmentors. These people find difficulty in switching their roles. At the home also they always looking in their official mail account. They struggle to manage their work life balance. The company focusses on integrators and formulate practices which help them to management work and life efficiently.

- $20 \%$ Creativity- Google allows employees set an annual goal of their choice. For this they allow to work $20 \%$ of the time in the weekends on the project that they aspire. This phenomenon promotes imagination, employee engagement and decreases turnover. The Gmail is one of the outcomes of these programme.

- High level of Flexibility- The recruitment process of Google is one of the thorough and lengthy process. They select only trustworthy candidates. One of the core values of the company is "If you give people freedom, they will amaze you". Some of the Google sites provide world class amenities like gaming rooms, massage, playgrounds. Employees can visit these places whenever they want. Google allows flexi schedules, work from home when they need and most important, they promote giving personal time to the employees for the family 'in hours' usually in the afternoon.

- Promotes Diversity- By the survey which Google conducts every year, they observe keenly that which country or gender lacks behind in their company. In one the gDNA results analytics, it was observed that fewer female was getting promoted as compare to male. They analysed carefully and found that in their policy of 'self- promoting' fewer females found themselves ready to take up the new responsibility. They discussed with the HR managers and ask them to look for the candidates who have the efficient. In a short time, the gap marginalised.

- $\quad$ Listening, responding and adapting- Google devised various tool for this purpose

- Google Moderator- Employees use this tool to ask questions and they can also give vote to the which they want to be answered.

- Every Friday a meeting is organised and the most popular questions are being answered by the leaders of the company.

o Google-O-Meter- This is a charting tool used to measure the popularity of different suggestions given by the employees.

○ Fixits- These are scheduled by the leaders to solve urgent problems within 24 hours.

The CareerGuru.concept in the Google provides a futuristic view of what it takes to be in different roles as a high-level executive. This helps the employees to assume themselves in their preferable role and follow the guidance by the leader in order to be eligible for that role.

\section{DISCUSSION AND SUGGESTIONS}

- The economical and affordable education can act as an impetus for reducing stress of $80 \%$ of the population in India. There should be a third-party inclusion for assuring the quality education to every child up to class 5 or 8 .

- There should an agreement between an employer and employee that if in case the company is at the edge of liquidation, the same should be notified at least before a year so that the employees can look for alternative arrangements. This would prevent the sudden shock and will give a sufficient time to searching for the new job.

- In spite of giving financial aid in various forms the minimum wage should be increased to an average level. This would help the workers to save themselves from vicious circle of credit and interest payment.

- Every company in India (public as well as private limited) should undertake volunteering initiative at their own level. Moreover, company can formulate new titles like 'humanity saviour' or 'environment 


\section{International Journal of Engineering Applied Sciences and Technology, 2020 Vol. 5, Issue 8, ISSN No. 2455-2143, Pages 273-277 \\ Published Online December 2020 in IJEAST (http://www.ijeast.com)}

saviour' in the same way as the employee of the month for encouraging to try their hands-on social services. This selfless contribution of employees changes the personal outlook of individuals at the same time company can repay in this form for the resources they are utilizing.

- Every institution should conduct employee survey every year. This has been followed in multinational companies. The results of the survey should be analysed and reported to the top authority. This could help the company to solve the problems faced by majority of employees and HR managers can communicate with team leaders to address the problem of individual employees. This helps in boosting morale and reduces the rate of attrition.

- In Indian Scenario an employee stays more than 9-5 to complete the task. The other dimensions of their personality somewhat freeze in between these timings. $20 \%$ creativity principle can work as an instrument to think beyond the limits. The company can formulate a plan where employee can choose any of the model or project and work around $20 \%$ of the office time in this model. The shift enhances the creativity and reduces the outburst to minimum level.

- Engaging the employee in their most efficient time is much better than engaging for fixed 8 to 9 hours. The studies have showed that the time in which employees work with zeal or maximum efficiency is the morning time. The work at government departments, banks starts in the afternoon. This is the time of low efficiency. So, there should be change in the timings especially for the institutions who deal with public directly to break monotonous nature of the working.

- Employee should be allowed to work on flexi hour basis in private as well as government sector. A week work time limit is more conducive. An employee should be allowed to work for 12 hour a day of 3 hour a day depending upon his/her adjustments. This policy help in maintaining better work-life balances.

\section{LIMITATIONS AND SCOPE OF THE STUDY}

The research is based on secondary sources. The primary data would more effectively convey the problems faced in work life balance. The work-life balance practices followed by only one company is taken into the study due to time constraint. The comparative analysis of work-life balance practices of big films would give better insight and would help in deriving dynamic solution. The sector centred, institution centred or gender centred study will give broader overview of the worklife balance. The search acts a base for comparative analysis.

\section{CONCLUSION}

Covid-19 lockdown period gave a balance for adjusting the work and family. But if we look around there are health practitioners, doctors, police department, municipal corporation, media who did not got a day off since the pandemic arrived. Do they would be able to maintain the balance? In a nutshell we can say that the concept of worklife balance is not a personal but also a social oriented concept. Every person is related to us directly or indirectly is contributing for work- life balance. It is the need of the hour to understand the importance of family and work and to put them in same parameter. The sector of the economy who wishes to sustain the active and potential workforce, they should think upon the work practices which increase the value of life which in turn enhanced the value of the society and ultimately the nation.

\section{REFERENCES}

(1) Ani Birgit Raiden, Christine Raisanen. (2013). Striving to achieve it all: men and work-family-life balance in Sweden and the UK. Construction Management and Economics 31:8, (pp. 899-913).

(2) Chaitra, R. (n.d.)(2016). A study on work life balance of employess at Bosch ltd, Banglore.BIMS International Journal of Social Science Research, (pp.61-68).

(3) Clark, SC. (2000). Work/family border theory: A new theory of work/family balance. Human Relations, (pp. 747-770).

(4) Hema, Mirji and D. K. (2011). Indian perspective on work life balance. Chronicle of the Neville Wadia Institute of Management studies and Research, (pp. 61-66).

(5) HILL, E.J., MILLER, B.C., WEINER, S.P. and COLIHAN, J. (1998), INFLUENCES OF THE VIRTUAL OFFICE ON ASPECTS OF WORK AND WORK/LIFE BALANCE. Personnel Psychology, 51: 667-683. https://doi.org/10.1111/j.1744-6570.1998.tb00256.x

(6) Jena, Lalatendu \& Mohanty, Atasi. (2016). WorkLife Balance Challenges for Indian Employees: SocioCultural Implications and Strategies. Journal of Human Resource and Sustainability Studies. 4. (pp.15-21). 10.4236/jhrss.2016.41002.

(7) Kalliath, T. \& Brough, P. (2008). Work-life balance: A review of the meaning of the balance construct. Journal of Management \& Organization, 14(3), (pp.323-327). doi:10.5172/jmo.837.14.3.323

(8) Khare, Ajit Kumar and Kapoor, Anupam.(2019). A Study on Work Life Balance Among Women Labor in Garment Units of NCR, India. International Journal of Management, 10 (1), (pp. 19-25).Retrieved from https://ssrn.com/abstract $=3526712$

(9) Kumar, Mohan. (2011) Work Life Balance in India - An Innovative Approach. Retrieved from SSRN: https://ssrn.com/abstract $=1803884$ or http://dx.doi.org/10.2139/ssrn.1803884 
(10) Smith, D. (2015). What's It Like to Work in Norway? Life in Norway. Retrieved from https://www.lifeinnorway.net/working-culture-norway/

(11) Steve, Fleetwood. (2007). Why work-life balance now?. The International Journal of Human Resource Management, 18:3, (pp. 387-400). DOI: $10.1080 / 09585190601167441$

(12) Sonders, M. (2018). 7 Employee Engagement Best Practices from the HR Experts at Google. Culture summit. Retrieved from https://www.culturesummit.co/articles/employeeengagement-best-practices/ 